\title{
Sex and gender considerations in Canadian clinical practice guidelines: a systematic review
}

\author{
Cara Tannenbaum MD MSc, Barbara Clow PhD, Margaret Haworth-Brockman MSc, Patrice Voss PhD
}

Abstract

Background: The importance of sex and gender in the diagnosis and management of health conditions is well established, but the extent to which this evidence is integrated into clinical practice guidelines remains unknown. We aimed to determine the proportion of Canadian clinical practice guidelines that integrate evidence on sex and gender considerations.

Methods: We searched the Canadian Medical Association's CPG Infobase, PubMed, all provincial/territorial websites and websites of professional organizations for English- and French-language Canadian clinical practice guidelines published between January 2013 and June 2015 on selected conditions identified as priorities by policy-makers and practitioners. Citations and text were searched electronically using keyword terms related to sex and gender. Three investigators independently analyzed and categorized the content of text-positive clinical practice guidelines based on clinical relevance for practitioners.

Results: Of the 118 clinical practice guidelines that met the inclusion criteria, 79 (66.9\%) were text-positive for sex and/or gender keywords; 8 (10\%) of the 79 used the keywords only in relation to pregnancy. Of the remaining 71 guidelines, 25 (35\%) contained sex-related diagnostic or management recommendations. An additional 5 (7\%) contained recommendations for sex-specific laboratory reference values, 29 (41\%) referred to differences in epidemiologic features or risk factors only, and 12 (17\%) contained nonrelevant mentions of search keywords. Twenty-five (35\%) of the text-positive guidelines used the terms "sex" and/or "gender" correctly.

Interpretation: Recommendations related to sex and gender are inconsistently reported in Canadian clinical practice guidelines. Guidelines such as the Sex and Gender Equity in Research guidelines may help inform the meaningful inclusion of sex and gender evidence in the development of clinical practice guidelines.

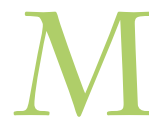
anifestations and outcomes of disease, including cardiovascular conditions, ${ }^{1-4}$ immune disease, ${ }^{5,6}$ respiratory illness ${ }^{6-8}$ and mental health conditions, ${ }^{9,10}$ have long been known to differ between men and women. These differences relate to sex (molecular, cellular and epigenetic mechanisms of male and female physiology) and gender (adopted or imposed social norms, behaviours, identities and expectations). ${ }^{11,12}$ Better understanding of these mechanisms has led to a near-linear rise in sex- and genderspecific research publications since the 1990s in all medical disciplines, ${ }^{13}$ although terminology can be confused. ${ }^{11}$

Despite new evidence on differences between males and females, the uptake of sex and gender influences into clinical practice guidelines and clinical practice has been slow. ${ }^{14}$ The development of clinical practice guidelines is a critical first step for translating research findings into clinical practice to narrow the "know-do" gap 15,16 and improve patient care. The consequences of not including evidence about females and males separately in clinical practice guidelines can range from missed opportunities to prevent type 2 diabetes in fathers of children whose mothers had gestational diabetes ${ }^{17}$ to inappropriate prescription of certain cardiovascular drugs to women based on altered risk-benefit profiles. ${ }^{18}$ For example, in 2014, Health Canada issued a warning to cut the recommended dosage of zolpidem, a common sleeping pill, for women by half because morning blood levels of the drug are

Competing interests: Barbara Clow and Margaret Haworth-Brockman received consulting fees from the Institute of Gender and Health, Canadian Institutes of Health Research during the conduct of the study.

This article has been peer reviewed.

Correspondence to: cara.tannenbaum@umontreal.ca

CMAJ Open 2017. DOI:10.9778/cmajo.20160051 
higher in women than in men, with increased risk of driving impairment. ${ }^{19}$ Rochon and colleagues ${ }^{20}$ discovered that, in Ontario, men with dementia who were prescribed antipsychotic drugs had significantly higher risks for hospital admission and death than did women with dementia. Similarly, social risk factors are associated with higher rates of suicide in older men, which suggests that more aggressive screening and treatment may be required..$^{21-23}$

The extent to which evidence about sex and gender is integrated into clinical practice guidelines for diagnosis and management of diseases remains unknown. We conducted a systematic review to investigate the integration of sex and gender evidence into Canadian clinical practice guidelines published between 2013 and 2015 for noncommunicable health conditions.

\section{Methods}

\section{Data sources and inclusion criteria}

Protocols for this review are posted on Open Science Framework and follow PRISMA (Preferred Reporting Items for Systematic Reviews and Meta-Analyses) reporting guidelines (www.prisma-statement.org/). The review search focused on selected health conditions identified as priorities by policymakers and practitioners ${ }^{24-30}$ (Box 1). We considered only 2 cancers, lung and colorectal, because they are among the leading causes of death from cancer for both females and males, ${ }^{31}$ and important sex and/or gender differences in prev-

\begin{tabular}{|c|c|}
\hline Acute coronary syndrome & Fibromyalgia \\
\hline Addictions & Generalized anxiety disorder \\
\hline Alcohol drinking & Heart failure \\
\hline Angina pectoris & Hypertension \\
\hline Anxiety disorders & Insomnia \\
\hline Asthma & Mental health conditions \\
\hline Atrial fibrillation & Migraine \\
\hline Back pain & Myocardial ischemia \\
\hline Cancer, colorectal & Neuralgia \\
\hline Cancer, general & Obesity \\
\hline Cancer, lung & Osteoarthritis \\
\hline Cardiomyopathies & Pain \\
\hline Cardiovascular diseases & Peripheral vascular diseases \\
\hline $\begin{array}{l}\text { Chronic obstructive pulmonary } \\
\text { disease }\end{array}$ & $\begin{array}{l}\text { Polyps } \\
\text { Pulmonary embolism }\end{array}$ \\
\hline Coronary artery disease & Pulmonary hypertension \\
\hline Dementia & Stroke \\
\hline Depression & Substance dependence \\
\hline Diabetes & Thrombosis \\
\hline Diabetic nephropathies & Transient ischemic attacks \\
\hline Dyslipidemias & Venous thromboembolism \\
\hline Emphysema & \\
\hline
\end{tabular}

alence, risk and screening, pathophysiologic characteristics, diagnosis, treatment and outcomes for these conditions have been found. ${ }^{32-36}$

We searched the Canadian Medical Association's database (CPG Infobase) of about 1200 clinical practice guidelines developed or endorsed by authoritative medical or health organizations in $\mathrm{Canada}^{37}$ for guidelines related to the identified health conditions. We also searched PubMed, all Canadian provincial/territorial websites and professional association websites for English- and French-language clinical practice guidelines using the search term "clinical practice guideline." Only documents published in Canada between January 2013 and June 15, 2015 were included. We chose these dates because Health Canada's Health Portfolio Sex and Gender-Based Analysis Policy ${ }^{38}$ was issued in 2009; new research under the policy would be published 1 to 2 years later, and at least 2 more years are required to review evidence and develop a clinical practice guideline. ${ }^{16} \mathrm{We}$ excluded original research, reviews, opinion pieces and editorials as well as clinical practice guidelines for single-sex health conditions such as menopause and prostate or gynecologic cancers. Duplicates were removed.

\section{Data extraction and quality assessment}

We searched the text and citations of clinical practice guidelines electronically for the keywords "sex," "gender," "male," "female," "men," "women," "man," "woman," "boy," "girl” and "pregnan*" We searched for clinical practice guidelines in French using the keywords "sexe," "genre," "sexospecifique," "homme," "hommes," "femme," "femmes," "fille," "filles," "garçon," "garçons" and "grossesse." We did not perform risk-of-bias assessments, as there is no validated strategy for sex and gender integration in clinical practice guidelines. Guidelines were considered text-positive if they had any keywords in the main text and text-negative if they had no keywords in the main text.

\section{Data synthesis and analysis}

We assigned guidelines that covered more than 1 health condition to the condition most emphasized in the text. Text-positive and text-negative guidelines were treated separately. Three investigators (C.T., B.C. and M.H.-B.) independently analyzed the content of every text-positive guideline for the type, amount and applicability of evidence presented on epidemiologic features, risk and screening, pathophysiologic characteristics, symptoms and diagnosis, and treatment/interventions. ${ }^{14}$

We assigned text-positive guidelines to 1 of 5 categories according to the relevance of the information to clinical practice. Guidelines were assigned to category 1 if evidenceinformed recommendations were made that supported different approaches for men and women, and to category 2 if the evidence presented supported the use of a singular approach for women and men. Category 3 included guidelines with sexspecific reference values for laboratory data. Guidelines that reported sex or gender differences in epidemiologic features or risk factors but did not make suggestions for clinical management were assigned to category 4 . Category 5 was reserved for 
guidelines that made only superficial mention of 1 or more of the search terms. The use of "sex" and "gender" specifically was assessed for adherence to current definitions. ${ }^{11,38}$ Differences in categorization were resolved by consensus.

\section{Outcomes}

The primary outcome of the review was the proportion of clinical practice guidelines that mentioned sex or gender or both, defined as the number of guidelines that were textpositive for any keyword over the total number of guidelines included in the review. Secondary outcomes were a qualitative analysis $^{39}$ of whether the inclusion of evidence in the text was clinically relevant, and the appropriate use of the terms "sex" and "gender" according to the Sex and Gender Equity in Research guidelines. ${ }^{11}$

\section{Statistical analysis}

We did not conduct statistical analyses of guideline data as the intent of this review was strictly to identify and categorize any mentions of sex- or gender-related words in the clinical practice guideline texts.

\section{Results}

The search identified 347 Canadian clinical practice guidelines that addressed 1 or more of the health conditions under consideration. We excluded 229 guidelines because of publication before 2013, a sex-specific topic or duplication, yielding 118 guidelines for final inclusion in the analysis (Figure 1), 3 of which were in French only.

\section{Inclusion of sex and/or gender information}

Of the 118 clinical practice guidelines, 79 (66.9\%) were textpositive for sex and gender keywords. Eight of the 79 (10\%) used keywords only in relation to pregnancy. Of the 71 remaining guidelines, 25 (35\%) contained sex-related diagnostic or management recommendations; 21 (30\%) recommended different approaches for men and women, and $4(6 \%)$ recommended similar approaches based on evidence (categories 1 and 2, respectively). Five guidelines (7\%) included recommendations for sex-specific laboratory reference values (category 3). Twenty-nine guidelines (41\%) referred to differences in epidemiologic features or risk factors only (category 4), and $12(17 \%)$ contained mentions not relevant to clinical practice (category 5).

Of the 39 text-negative guidelines, 5 (13\%) contained citations in the reference lists alluding to the presence of sex differences in the condition of interest. For example, a guideline on the pharmacological management of chronic neuropathic pain contained no keywords in the body of the text but cited 2 articles on the effects of sustained-action opioids on women and men. ${ }^{40}$

\section{Type of sex and gender evidence cited in text- positive clinical practice guidelines}

The nature of sex-specific information reported in textpositive clinical practice guidelines varied (Table 1). For example, 1 guideline stated that "colorectal cancer is the third most common cancer ... in both sexes," ${ }^{68}$ whereas a few provided sex-disaggregated risk and mortality data, such as "The probability of developing colorectal cancer increases with age and varies with sex ... i.e., 1/32 males and 1/36 females will die of invasive colorectal cancer." ${ }^{69,70}$

Other guidelines mentioned sex as a risk factor but only in absolute terms, such as noting that female sex is a risk factor for depression in patients with diabetes ${ }^{71}$ or that female adolescents with type 1 diabetes are at risk for eating disorders. ${ }^{72}$ Sometimes the comparative risk of different outcomes in men and women was mentioned in broad terms, such as following stroke, when women are at greater risk for depression whereas men are at greater risk for vascular dementia. ${ }^{73}$ In rare instances, sex differences in risk were explicit: "Estimates of risk of ischemic stroke in people with diabetes range from a 2 - to 3 -fold increase in men and a 2 - to 5 -fold increase in women." 74 In only 2 cases were gender differences noted, as in the case of perceptions and interpretations of pain. ${ }^{67}$

Some guidelines provided evidence that can inform clinical practice. For example, guidelines on alcohol consumption recommended a lower diagnostic screening threshold for risky drinking behaviour for women than for men, ${ }^{53,54,75}$ although only 1 guideline explained biological differences in alcohol absorption rates by sex. ${ }^{53}$ Another guideline suggested that women respond more favourably than men to outpatient care. ${ }^{75}$ Two guidelines alluded to hormonal causal pathways for aggravated hypertension in women, highlighting modifiable treatment strategies in the form of discontinuation of oral contraceptive and exogenous sex hormone therapies. ${ }^{45,76} \mathrm{~A}$ recommendation to avoid antidepressants with strong cytochrome P450 2D6 inhibition (e.g., paroxetine, fluoxetine) in premenopausal survivors of breast cancer requiring tamoxifen therapy can be applied in practice. ${ }^{77}$ As well, a guideline on heart failure in children and youth warned that treatment with spironolactone can lead to irreversible gynecomastia in males, affecting long-term psychological outcomes. ${ }^{78}$

Conversely, some guidelines did not address the clinical implications of sex and gender differences. A guideline noting differences in response to medication between male and female children and adolescents with type 2 diabetes did not recommend distinct treatment choices. ${ }^{72}$ Similarly, guidelines that described a higher rate of adverse effects of statin use in women than in men did not offer assistance for selecting alternative therapies to lower lipids..$^{59,79,80}$

\section{Uses of "sex"and "gender" evidence in clinical practice guidelines}

Text-positive clinical practice guidelines also varied in the correct use of the terms "sex" and "gender." Of the 79 guidelines, 37 (47\%) did not use either term explicitly, 14 $(18 \%)$ used one or the other, but not according to the accepted definitions, and $25(32 \%)$ used at least 1 term appropriately. One guideline (1\%) used "sex" in the context of sexual activity only. 


\section{Interpretation}

We found inconsistencies in the extent and degree to which evidence on sex and gender is incorporated into Canadian clinical practice guidelines. Only $35 \%$ of guidelines reported screening, diagnosis or management considerations specific to sex or gender, and only $25 \%$ used the terms "sex" and "gender" correctly. Given early recognition of sex and gender differences in mental health conditions and cardiovascular disease, we expected clinical practice guidelines in these fields to reliably highlight information about females and males separately. ${ }^{13}$ Recent attention to sex differences in cancer ${ }^{81-83}$ lung disease ${ }^{6-8}$ and diabetes ${ }^{84-86}$ predicted meaningful uptake in these areas as well. Although some clinical practice guidelines targeting these conditions incorporated differentiated data in a way that guides practice, many keyword mentions were superficial and of limited value.

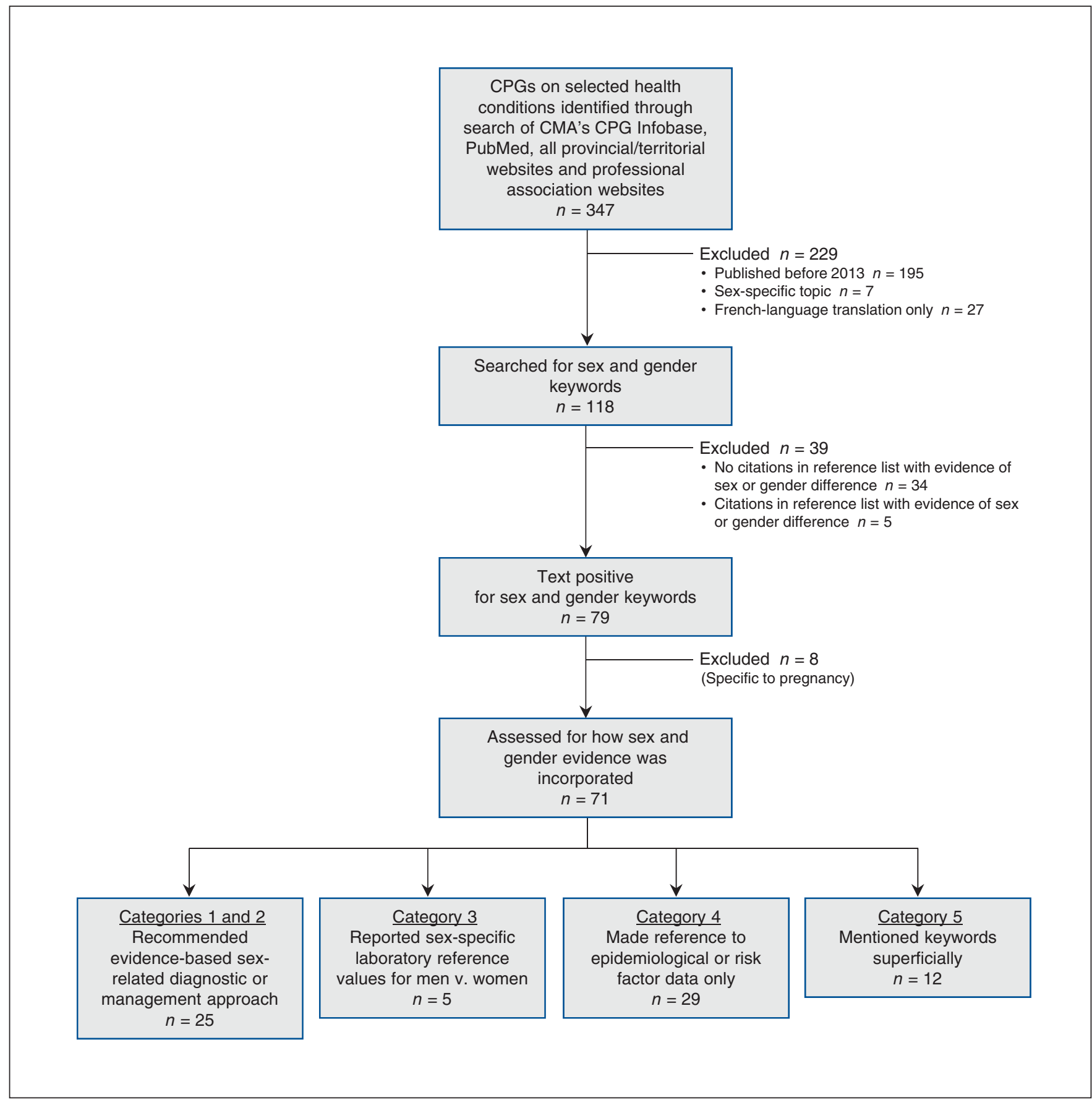

Figure 1: Flowchart showing the inclusion and exclusion criteria that were applied to the initial sample of 347 Canadian clinical practice guidelines on selected health conditions. A total of 71 text-positive guidelines were categorized as a function of the clinical relevance of the information provided. $\mathrm{CMA}=$ Canadian Medical Association, $\mathrm{CPG}=$ clinical practice guideline. 


\begin{tabular}{|c|c|c|}
\hline Condition & Quote from guideline & Group \\
\hline \multicolumn{3}{|c|}{ Guideline specifically recommends evidence-based diagnostic or management approach for men/women or boys/girls } \\
\hline Ischemic heart disease & $\begin{array}{l}\text { Noninvasive testing not normally recommended for } \\
\text { women }<60 \text { years of age or men }<40 \text { years of age with } \\
\text { only } 1 \text { classical risk factor for angina }\end{array}$ & Canadian Cardiovascular Society ${ }^{41}$ \\
\hline Stroke & $\begin{array}{l}\text { Acetylsalicylic acid recommended for reducing the risk of } \\
\text { stroke in women only. Stroke unit care is equally } \\
\text { beneficial for men and women. }\end{array}$ & $\begin{array}{l}\text { Canadian Stroke Best Practices and } \\
\text { Standards Working Group }{ }^{42}\end{array}$ \\
\hline Diabetes & $\begin{array}{l}\text { Acetylsalicylic acid recommended for reducing nonfatal } \\
\text { myocardial infarction in men but not women without a } \\
\text { history of cardiovascular disease }\end{array}$ & $\begin{array}{l}\text { Canadian Diabetes Association Clinical } \\
\text { Practice Guidelines Expert Committee }{ }^{43}\end{array}$ \\
\hline Childhood diabetes & $\begin{array}{l}\text { Adolescent females with type } 1 \text { diabetes should be } \\
\text { regularly screened for eating disorders using } \\
\text { nonjudgmental questions about weight and body image }\end{array}$ & $\begin{array}{l}\text { Canadian Diabetes Association Clinical } \\
\text { Practice Guidelines Expert Committee }{ }^{44}\end{array}$ \\
\hline Hypertension & $\begin{array}{l}\text { Recommended target of a healthy body weight (body } \\
\text { mass index } 18.5-24.9 \mathrm{~kg} / \mathrm{m}^{2} \text {, with a waist circumference } \\
<102 \mathrm{~cm} \text { for men and }<88 \mathrm{~cm} \text { for women) }\end{array}$ & $\begin{array}{l}\text { Canadian Hypertension Education } \\
\text { Program, }{ }^{45-48} \text { Canadian Diabetes Association } \\
\text { Clinical Practice Guidelines Expert } \\
\text { Committee }^{49}\end{array}$ \\
\hline Dyslipidemia & $\begin{array}{l}\text { Recommend plasma lipid screening in men }>40 \text { years } \\
\text { for low high-density lipoprotein }(<1.0 \mathrm{mmol} / \mathrm{L}) \text { and in } \\
\text { women }>50 \text { years for low high-density lipoprotein } \\
\text { (<1.3 mmol/L) }\end{array}$ & $\begin{array}{l}\text { Canadian Diabetes Association Clinical } \\
\text { Practice Guidelines Expert Committee, }{ }^{50} \\
\text { Canadian Cardiovascular Harmonized } \\
\text { National Guidelines Endeavour }{ }^{51}\end{array}$ \\
\hline $\begin{array}{l}\text { Primary prevention of } \\
\text { childhood obesity }\end{array}$ & $\begin{array}{l}\text { Educational interventions with a social learning } \\
\text { foundation may be more effective with girls, while } \\
\text { interventions that change environment to enable physical } \\
\text { activity may be more effective with boys }\end{array}$ & Registered Nurses' Association of Ontario ${ }^{52}$ \\
\hline $\begin{array}{l}\text { Low risk drinking } \\
\text { guidelines }\end{array}$ & $\begin{array}{l}\text { Screen for at-risk drinking in men }<65 \text { years: } 5 \text { or more } \\
\text { drinks on } 1 \text { or more days in the last year. Limit to no } \\
\text { more than } 3 \text { drinks in any day, } 15 \text { per week. } \\
\text { Screen women }<65 \text { years for } 4 \text { or more drinks on } \\
1 \text { or more days in the last year. Limit to no more than } \\
2 \text { drinks in any day, } 10 \text { per week. }\end{array}$ & $\begin{array}{l}\text { Collège des médecins du Québec/ } \\
\text { Éduc'alcool, }{ }^{53} \text { British Columbia Ministry of } \\
\text { Health }\end{array}$ \\
\hline \multicolumn{3}{|c|}{ Guideline acknowledges different laboratory reference values for men/women or boys/girls } \\
\hline Heart failure & $\begin{array}{l}\text { Recommends using World Health Organization definition } \\
\text { of anemia: hemoglobin concentration }<130 \mathrm{~g} / \mathrm{dL} \text { for men } \\
\text { and }<120 \mathrm{~g} / \mathrm{dL} \text { for women }\end{array}$ & Canadian Cardiovascular Society ${ }^{56}$ \\
\hline Diabetic nephropathy & $\begin{array}{l}\text { 4-variable Modification of Diet in Renal Disease equation } \\
\text { requires knowledge of the patient's sex for laboratory } \\
\text { calculation of the estimated glomerular filtration rate }\end{array}$ & $\begin{array}{l}\text { Canadian Diabetes Association Clinical } \\
\text { Practice Guidelines Expert Committee }{ }^{57}\end{array}$ \\
\hline Asthma & Spirometry reference values determined by sex & Canadian Thoracic Society ${ }^{58}$ \\
\hline \multicolumn{3}{|c|}{ Guideline mentions epidemiologic or risk factor data only, without recommendations } \\
\hline Dyslipidemia & $\begin{array}{l}\text { Women }>80 \text { years are at increased risk for statin- } \\
\text { induced myopathy }\end{array}$ & $\begin{array}{l}\text { Canadian Diabetes Association Clinical } \\
\text { Practice Guidelines Expert Committee }{ }^{59}\end{array}$ \\
\hline Heart failure & $\begin{array}{l}\text { Female patients are more likely to have nonischemic } \\
\text { cardiomyopathy. Making a diagnosis of heart failure in } \\
\text { women is considered to be more difficult, because the } \\
\text { cardinal triad of edema, fatigue and dyspnea are neither } \\
\text { sensitive nor specific manifestations and atypical } \\
\text { presentations occur more frequently. }\end{array}$ & Canadian Cardiovascular Society ${ }^{60}$ \\
\hline Diabetes & $\begin{array}{l}\text { Thiazolidinediones increase the risk of fracture in older } \\
\text { women } \\
\text { Aboriginal women in Canada have a } 2 \text { to } 3 \text { times higher } \\
\text { rate of gestational diabetes than others }\end{array}$ & $\begin{array}{l}\text { Canadian Diabetes Association Clinical } \\
\text { Practice Guidelines Expert Committee }{ }^{50}\end{array}$ \\
\hline Anxiety disorders & $\begin{array}{l}\text { Women generally have higher prevalence rates for most } \\
\text { anxiety disorders, compared to men }\end{array}$ & $\begin{array}{l}\text { Canadian Anxiety Guidelines Initiative } \\
\text { Group }{ }^{61}\end{array}$ \\
\hline Substance dependence & $\begin{array}{l}\text { Gender identity and gender expression are risk factors } \\
\text { for a substance use disorder owing to widespread } \\
\text { marginalization and discrimination }\end{array}$ & Registered Nurses' Association of Ontario ${ }^{62}$ \\
\hline Colon cancer & $\begin{array}{l}\text { The risk for devepment of colon cancer is higher in } \\
\text { males than in females. } \\
\text { Female sex is associated with more adverse events from } \\
\text { colonoscopy, longer duration and incomplete } \\
\text { examinations. }\end{array}$ & Cancer Care Ontario 63,64 \\
\hline \multicolumn{3}{|c|}{ Guideline makes superficial reference to the keywords sex, gender, men/women or boys/girls } \\
\hline Coronary artery disease & Only $28 \%$ of the patients in the trial were women & $\begin{array}{l}\text { Canadian Cardiovascular Society Heart } \\
\text { Failure Management Primary Panel }{ }^{65}\end{array}$ \\
\hline $\begin{array}{l}\text { Chronic obstructive } \\
\text { pulmonary disease }\end{array}$ & $\begin{array}{l}\text { Benefits of antibiotic administration on exacerbation } \\
\text { rates were significant in } 1 \text { study, even after adjustment } \\
\text { for sex }\end{array}$ & $\begin{array}{l}\text { American College of Chest Physicians/ } \\
\text { Canadian Thoracic Society }{ }^{66}\end{array}$ \\
\hline Pain & Pain scale has 6 gender-neutral faces & Registered Nurses' Association of Ontario ${ }^{67}$ \\
\hline
\end{tabular}


These findings are similar to those reported from the Netherlands, where a preliminary study showed that sexrelated factors or effects were mentioned in only $20 \%$ of clinical practice guideline recommendations for osteoporosis and were completely absent in clinical practice guidelines on depression. ${ }^{87}$

Several reasons may account for the variable inclusion of disaggregated evidence in clinical practice guidelines. A simple explanation is the lack of research on sex and gender differences in medicine. With most biomedical experiments conducted exclusively on male animals and substantial underrepresentation of women in clinical trials, it is possible that many sex and gender differences have yet to be discovered..$^{88,89}$ Although more publications that consider females and males separately in medicine are emerging, less than $25 \%$ address differences in management decisions for patients based on sex or gender. ${ }^{13}$

Another explanation for the suboptimal integration of sex and gender considerations into clinical practice guidelines relates to the lag time between research discovery and practice transformation. ${ }^{90,91}$ A recent study showed that microglial cells play a role in mediating pain pathways in male mice, whereas $\mathrm{T}$ cells are responsible for this same function in female mice. ${ }^{92}$ It is not known when and how this information will translate into different analgesic drug targets for men and women. Pharmacoepidemiological findings and postmarketing drug safety warnings on the differential risks of adverse drug reactions in women and men do not seem to substantially change entrenched prescribing patterns..$^{93}$ Future clinical practice guidelines on insomnia should incorporate Health Canada's 2014 recommendation to cut the dosage of sleeping pills in half for women. ${ }^{19}$

Finally, failure to integrate such considerations into clinical practice guidelines likely results from lack of awareness as well as lack of guidance on how to do so. ${ }^{87,94,95}$ Current guideline development instruments do not provide instruction for synthesizing sex and gender evidence. ${ }^{96}$ The AGREE (Appraisal of Guidelines, Research and Evaluation) II instrument requires systematic reviewers to specify populations of interest, but does not require identification of evidence particular to males or females or any note of sex or gender differences. ${ }^{97}$ The same is true for GRADE (Grading of Recommendations Assessment, Development and Evaluation) guidelines. ${ }^{98-100}$ Unless a clinical practice guideline working group specifically asks a question about evidence-based sex and gender differences, it is unlikely that the correct search terms will be used to query the literature.

Several instruments exist to guide the inclusion of sex and gender. The Health Equity Group at Cochrane Canada encourages systematic reviewers to consider sex, gender and other equity dimensions, providing user templates. ${ }^{101}$ The Sex and Gender Equity in Research guidelines provide rationales and guidance for clinical practice guideline reviewers to look for and incorporate evidence on sex differences and gender and to use the terms appropriately. ${ }^{11,102}$ Song and colleagues ${ }^{103}$ published a validated search strategy for uncovering publications that report sex-specific diagnostic and treatment evi- dence. Standardized application of these strategies could enhance the uptake of evidence that is sex and gender specific in future clinical practice guidelines.

\section{Limitations}

A strength of our systematic review is that we used Canadian, provincial and academic Web sources to search for clinical practice guidelines, and the search terms were broad and inclusive. One limitation is that our findings risk overestimating perceptions that sex and gender evidence is meaningfully integrated into Canadian clinical practice guidelines. Ultimately, only $25(21.2 \%)$ of the 118 clinical practice guidelines included in our review provided relevant sex-related diagnostic or management recommendations. We did not perform risk-of-bias assessments of the quality of the guidelines. A systematic search for sex- and gender-specific evidence that was omitted from clinical practice guidelines would permit an assessment of any missed opportunities to appropriately include information about male and female patients in clinical practice guidelines.

\section{Conclusion}

Gender-responsive health care takes into account all sex- and gender-related factors for women and men. Practitioners are increasingly requiring male- and female-specific information. For example, specialists in heart failure have explicitly called for sex-specific diagnostic criteria and treatments. The implications of this systematic review on future clinical practice guideline development are twofold. First, we suggest that guidelines for developing clinical practice guidelines be revised to emphasize the importance of including subquestions and search strategies that reveal evidence on sex and gender differences in medicine. Second, we recommend that a focus on sex- and gender-responsive interventions be prioritized not only in clinical practice guidelines but also in medical school curricula and continuing education to consolidate Canadian innovation in personalized care.

\section{References}

1. Koeth O, Zahn R, Heer T, et al. Gender differences in patients with acute ST-elevation myocardial infarction complicated by cardiogenic shock. Clin Res Cardiol 2009;98:781-6.

2. Letsas KP, Efremidis M, Kounas SP, et al. Clinical characteristics of patients with drug-induced QT interval prolongation and torsade de pointes: identification of risk factors. Clin Res Cardiol 2009;98:208-12.

3. Nieminen MS, Harjola V, Hochadel M, et al. Gender related differences in patients presenting with acute heart failure. Results from EuroHeart Failure Survey II. Eur 7 Heart Fail 2008;10:140-8.

4. Schirmer SH, Hohl M, Bohm M. Gender differences in heart failure: Paving the way towards personalized medicine? Eur Heart 7 2010;31:1165-7.

5. Rubtsova K, Marrack P, Rubtsov AV. Sexual dimorphism in autoimmunity. $f$ Clin Invest 2015;125:2187-93.

6. Giefing-Kröll C, Berger P, Lepperdinger G, et al. How sex and age affect immune responses, susceptibility to infections, and response to vaccination. Aging Cell 2015;14:309-21.

7. Casimir GJ, Lefèvre N, Corazza F, et al. Sex and inflammation in respiratory diseases: a clinical viewpoint. Biol Sex Differ 2013;4:16.

8. Robles PG, Brooks D, Goldstein R, et al. Gender-associated differences in pulmonary rehabilitation outcomes in people with chronic obstructive pulmonary disease: a systematic review. 7 Cardiopulm Rehabil Prev 2014;34:87-97.

9. Hill TD, Needham BL. Rethinking gender and mental health: a critical analysis of three propositions. Soc Sci Med 2013;92:83-91.

10. Seedat S, Scott KM, Angermeyer MC, et al. Cross-national associations between gender and mental disorders in the World Health Organization World Mental Health Surveys. Arch Gen Psychiatry 2009;66:785-95. 
11. Heidari S, Babor TF, De Castro P, et al. Sex and Gender Equity in Research: rationale for the SAGER guidelines and recommended use. Res Integr Peer Rev 2016;1:2

12. Johnson JL, Greaves L, Repta R. Better science with sex and gender: facilitating the use of a sex and gender-based analysis in health research. Int 7 Equity Health 2009;8:14.

13. Oertelt-Prigione S, Parol R, Krohn S, et al. Analysis of sex and genderspecific research reveals a common increase in publications and marked differences between disciplines. BMC Med 2010;8:70.

14. Keuken DG, Haafkens JA, Hellema MJ, et al. Incorporating a gender perspective into the development of clinical guidelines: a training course for guideline developers. Implement Sci 2007;2:35.

15. Pablos-Mendez A, Shademani R. Knowledge translation in global health. $\mathcal{f}$ Contin Educ Health Prof 2006;26:81-6.

16. Green LW, Ottoson JM, García C, et al. Diffusion theory and knowledge dissemination, utilization, and integration in public health. Annu Rev Public Health 2009;30:151-74.

17. Dasgupta K, Ross N, Meltzer S, et al. Gestational diabetes mellitus in mothers as a diabetes predictor in fathers: a retrospective cohort analysis. Diabetes Care 2015;38:e130-1

18. Stolarz AJ, Rusch NJ. Gender differences in cardiovascular drugs. Cardiovasc Drugs Ther 2015;29:403-10.

19. Sublinox (zolpidem tartrate) - new dosage recommendations to minimize risk of next-day impairment in both women and men - for health professionals. Ottawa: Health Canada; 2014. Available: http://healthycanadians. gc.ca/recall-alert-rappel-avis/hc-sc/2014/37415a-eng.php (accessed 2015 Aug. 14).

20. Rochon PA, Gruneir A, Gill SS, et al. Older men with dementia are at greater risk than women of serious events after initiating antipsychotic therapy. 7 Am Geriatr Soc 2013;61:55-61.

21. Eggertson L. Canada lacks national suicide prevention strategy. Lancet 2015; 385:2562-3

22. Murphy BJ, Bugeja L, Pilgrim J, et al. Completed suicide among nursing home residents: a systematic review. Int 7 Geriatr Psychiatry 2015;30:802-14.

23. Schiff LB, Holland KM, Stone DM, et al. Acute and chronic risk preceding suicidal crises among middle-aged men without known mental health and/or substance abuse problems: an exploratory mixed-methods analysis. Crisis 2015;36:304-15.

24. Terner M, Reason B, McKeag AM, et al. Chronic conditions more than age drive health system use in Canadian seniors. Healthc Q 2011;14:19-22.

25. Preventing chronic disease strategic plan 2013-2016. Ottawa: Public Health Agency of Canada; 2013. Available: http://publications.gc.ca/collections/ collection_2014/aspc-phac/HP35-39-2013-eng.pdf (accessed 2017 Jan. 19).

26. Changing directions, changing lives: the mental health strateoy for Canada. Calgary: Mental Health Commission of Canada; 2012. Available: http:// strategy.mentalhealthcommission.ca/pdf/strategy-images-en.pdf (accessed 2017 Jan. 6).

27. Rising to the challenge: a strategic plan for the mental health and well-being of Manitobans. Winnipeg: Government of Manitoba; 2011. Available: www. gov.mb.ca/healthyliving/mh/challenge.html (accessed 2015 June 5).

28. Together we can: the plan to improve mental health and addictions care for Nova Scotians. Halifax: Government of Nova Scotia; 2012. Available: http:// novascotia.ca/dhw/mental-health/mental-health-addiction-strategy.asp (accessed 2015 June 5).

29. Lynch ME. The need for a Canadian pain strategy. Pain Res Manag 2011;16: $77-80$.

30. The need for the comprehensive pain strategy in Ontario. Action Ontario. Available: http://actionontario.ca/the-need-for-the-comprehensive-painstrategy-in-ontario/ (accessed 2017 Jan. 6).

31. Cancer statistics at a glance. Toronto: Canadian Cancer Society; 2016. Available: www.cancer.ca/en/cancer-information/cancer-101/cancer-statistics-ata-glance/? region=on (accessed 2016 Sept. 24).

32. Brenner H, Haug U, Hundt S. Sex differences in performance of fecal occult blood testing. Am 7 Gastroenterol 2010;105:2457-64.

33. Doria-Rose VP, Newcomb PA, Levin TR. Incomplete screening flexible sigmoidoscopy associated with female sex, age, and increased risk of colorectal cancer. Gut 2005:54:1273-8.

34. Schoenfeld P, Cash B, Flood A, et al. Colonoscopic screening of average-risk women for colorectal neoplasia. N Engl 7 Med 2005;352:2061-8.

35. van Turenhout ST, Oort FA, van der Hulst RW, et al. Prospective crosssectional study on faecal immunochemical tests: Sex specific cut-off values to obtain equal sensitivity for colorectal cancer? BMC Gastroenterol 2014;14:217.

36. North CM, Christiani DC. Women and lung cancer: What is new? Semin Thorac Cardiovasc Surg 2013;25:87-94.

37. CPG Infobase: clinical practice guidelines database. Ottawa: Canadian Medical Association. Available: https://www.cma.ca/En/Pages/clinical-practiceguidelines.aspx (accessed 2015 Apr. 26).

38. Health Portfolio Sex and Gender-based Analysis Policy. Ottawa: Health Canada; 2010. Available: www.hc-sc.gc.ca/hl-vs/pubs/women-femmes/sgba -policy-politique-ags-eng.php (accessed 2015 June 30).

39. Bowen GA. Document analysis as a qualitative research method. Qual Res 7 2009;9:27-40.
40. Moulin D, Boulanger A, Clark AJ, et al. Pharmacological management of chronic neuropathic pain: revised consensus statement from the Canadian Pain Society. Pain Res Manag 2014;19:328-35.

41. Mancini GB, Gosselin G, Chow B, et al.; Canadian Cardiovascular Society. Canadian Cardiovascular Society guidelines for the diagnosis and management of stable ischemic heart disease. Can f Cardiol 2014;30:837-49.

42. Lindsay MP, Gubitz G, Bayley M, et al.; Canadian Stroke Best Practices and Standards Working Group. Summary of stroke best practice recommendations: 2012-2013 update. In: Canadian best practice recommendations for stroke care. 4th ed. Ottawa: Heart and Stroke Foundation; 2013: 13-81.

43. Stone JA, Fitchett D, Grover S, et al.; Canadian Diabetes Association Clinical Practice Guidelines Expert Committee. Vascular protection in people with diabetes. Can 7 Diabetes 2013;37(Suppl 1):S100-4.

44. Wherrett D, Huot C, Mitchell B, et al.; Canadian Diabetes Association Clinical Practice Guidelines Expert Committee. Type 1 diabetes in children and adolescents. Can 7 Diabetes 2013;37(Suppl 1):S153-62.

45. CHEP 2014 recommendations. Canadian Hypertension Education Program; 2014. Available: www.hypertension.ca/images/CHEP 2014/2014 CompleteCHEPRecommendations_EN_HCP1009.pdf (accessed 2015 May 30).

46. Daskalopoulou SS, Rabi DM, Zarnke KB, et al. The 2015 Canadian Hypertension Education Program recommendations for blood pressure measurement, diagnosis, assessment of risk, prevention, and treatment of hypertension. Can 7 Cardiol 2015;31:549-68.

47. Dasgupta K, Quinn RR, Zarnke KB, et al.; Canadian Hypertension Education Program. The 2014 Canadian Hypertension Education Program recommendations for blood pressure measurement, diagnosis, assessment of risk, prevention, and treatment of hypertension. Can 7 Cardiol 2014;30:485-501.

48. Hackam DG, Quinn RR, Ravani P, et al.; Canadian Hypertension Education Program. The 2013 Canadian Hypertension Education Program recommendations for blood pressure measurement, diagnosis, assessment of risk, prevention, and treatment of hypertension. Can 7 Cardiol 2013;29:528-42.

49. Cheng AY; Canadian Diabetes Association Clinical Practice Guidelines Expert Committee. Canadian Diabetes Association 2013 clinical practice guidelines for the prevention and management of diabetes in Canada. Introduction. Can 7 Diabetes 2013;37(Suppl 1):S1-3.

50. Meneilly GS, Knip A, Tessier D; Canadian Diabetes Association Clinical Practice Guidelines Expert Committee. Diabetes in the elderly. Can 7 Diabetes 2013;37(Suppl 1):S184-90.

51. Tobe SW, Stone JA, Walker KM, et al. C-CHANGE Initiative. Canadian Cardiovascular Harmonized National Guidelines Endeavour (C-CHANGE): 2014 update. CMA7 2014;186:1299-305.

52. Primary prevention of childhood obesity. 2nd ed. Toronto: Registered Nurses Association of Ontario; 2014.

53. Low-risk drinking guidelines: a guide for physicians and health care professionals. Montréal: Collège des médecins du Québec and Éduc'alcool; 2013. Available: http://www.cmq.org/publications-pdf/p-1-2013-02-01-en -niveaux-consommation-alcool-faible-risque.pdf (accessed 2017 Jan. 6).

54. Problem drinking part 1 - screening and assessment. Victoria: British Columbia Ministry of Health; 2013. Available: www2.gov.bc.ca/gov/content/health/ practitioner-professional-resources/bc-guidelines/problem-drinking\#part1 (accessed 2015 June 1)

55. Problem drinking part 2 - brief intervention. Victoria: British Columbia Ministry of Health; 2013. Available: www2.gov.bc.ca/gov/content/health/5 (accessed 2017 Jan. 6)

56. Moe GW, Ezekowitz JA, O'Meara E, et al.; Canadian Cardiovascular Society. The 2014 Canadian Cardiovascular Society heart failure management guidelines focus update: anemia, biomarkers, and recent therapeutic trial implications. Can 7 Cardiol 2015;31:3-16.

57. McFarlane P, Gilbert RE, MacCallum L, et al.; Canadian Diabetes Association Clinical Practice Guidelines Expert Committee. Chronic kidney disease in diabetes. Can 7 Diabetes 2013;37:S129-36.

58. Coates AL, Graham BL, McFadden RG, et al.; Canadian Thoracic Society. Spirometry in primary care. Can Respir 7 2013;20:13-21.

59. Mancini GB, Hegele RA, Leitner LA; Canadian Diabetes Association Clinical Practice Guidelines Expert Committee. Dyslipidemia. Can 7 Diabetes 2013;37(Suppl 1):S110-6.

60. McKelvie RS, Moe GW, Ezekowitz JA, et al. The 2012 Canadian Cardiovascular Society heart failure management guidelines update: focus on acute and chronic heart failure. Can 7 Cardiol 2013;29:168-81

61. Katzman MA, Bleau P, Blier P, et al.; Canadian Anxiety Guidelines Initiative Group on behalf of the Anxiety Disorders Association of Canada/Association Canadienne des troubles anxieux and McGill University. Canadian clinical practice guidelines for the management of anxiety, posttraumatic stress and obsessive-compulsive disorders. BMC Psychiatry 2014;14(Suppl 1):S1.

62. Engaging clients who use substances. Toronto: Registered Nurses' Association of Ontario; 2015.

63. Tinmouth J, Kennedy E, Baron D, et al. Guideline for colonoscopy quality assurance in Ontario. Toronto: Cancer Care Ontario; 2013. Program in Evidencebased Care Evidence-based Series no 15-5, version 2.

64. Tinmouth J, Kennedy EB, Baron D, et al. Colonoscopy quality assurance in Ontario: systematic review and clinical practice guideline. Can $\mathcal{F}$ Gastroenterol Hepatol 2014;28:251-74. 
65. Moe GW, Ezekowitz JA, O'Meara E, et al.; Canadian Cardiovascular Society Heart Failure Management Primary Panel. The 2013 Canadian Cardiovascular Society Heart Failure Management Guidelines Update: focus on rehabilitation and exercise and surgical coronary revascularization. Can 7 Cardiol 2014;30:249-63.

66. Criner GJ, Bourbeau J, Diekemper RL, et al. Prevention of acute exacerbations of COPD: American College of Chest Physicians and Canadian Thoracic Society Guideline. Chest 2015;147:894-942.

67. Assessment and management of pain. 3rd ed. Toronto: Registered Nurses' Association of Ontario; 2013.

68. Asmis T, Berry S, Cosby R, et al. Strategies of sequential therapies in unresectable metastatic colorectal cancer: a meta-analysis. Curr Oncol 2014;21:318-28.

69. Colorectal cancer screening: clinical practice guideline. Edmonton: Toward Optimized Practice Working Group for Colorectal Cancer Screening; 2013. Available: www.topalbertadoctors.org/download/1009/colorectal_guideline. pdf (accessed 2015 June 5).

70. Colorectal screening for cancer prevention in asymptomatic patients. Victoria: British Columbia Ministry of Health; 2013. Available: www2.gov.bc.ca/ assets/gov/health/practitioner-pro/bc-guidelines/colorectal_screening.pdf (accessed 2015 June 7).

71. Robinson DJ, Luthra M, Vallis M; Canadian Diabetes Association Clinical Practice Guidelines Expert Committee. Diabetes and mental health. Can 7 Diabetes 2013;37:S87-92.

72. Panagiotopoulos C, Riddell MC, Sellers EA; Canadian Diabetes Association Clinical Practice Guidelines Expert Committee. Type 2 diabetes in children and adolescents. Can 7 Diabetes 2013;37:S163-7.

73. Eskes G. Mood and cognition in patients following stroke. In: Lindsay MP, Gubitz G, Bayley M, et al., editors. Canadian best practice recommendations for stroke care. 4th ed. Ottawa: Heart and Stroke Foundation; 2013:1-40.

74. Sharma M, Gubitz GJ; Canadian Diabetes Association Clinical Practice Guidelines Expert Committee. Management of stroke in diabetes. Can 7 Diabetes 2013;37:S124-5.

75. Problem drinking part 3 - office based management of alcohol withdrawal and prescribing medications for alcohol dependence. Victoria: British Columbia Ministry of Health; 2013. Available: www2.gov.bc.ca/gov/content/ health/practitioner-professional-resources/bc-guidelines/problem-drinking\# part3 (accessed 2017 Jan. 6).

76. CHEP 2013 recommendations. Canadian Hypertension Education Program; 2013. Available: http://hypertension.ca/images/CHEP_2013/2013_ CompleteCHEPRecommendations_EN_HCP1009.pdf (accessed 2015 May 30).

77. Li M, Kennedy EB, Byrne N, et al. The management of depression in patients with cancer. Program in Evidence-based Guideline no 19-4. Toronto: Cancer Care Ontario: 2015. Available: https://www.cancercare.on.ca/common/pages/ UserFile.aspx? fileId=340750 (accessed 2015 June 15).

78. Kantor PF, Lougheed J, Dancea A, et al.; Children's Heart Failure Study Group. Presentation, diagnosis, and medical management of heart failure in children: Canadian Cardiovascular Society guidelines. Can 7 Cardiol 2013;29: 1535-52.

79. Cardiovascular disease - primary prevention. Victoria: British Columbia Ministry of Health; 2014. Available: www2.gov.bc.ca/assets/gov/health/ practitioner-pro/bc-guidelines/cvd.pdf (accessed 2015 May 28).

80. Mancini GB, Tashakkor AY, Baker S, et al. Diagnosis, prevention, and management of statin adverse effects and intolerance: Canadian Working Group Consensus update. Can 7 Cardiol 2013;29:1553-68.

81. Hoyt MA, Rubin LR. Gender representation of cancer patients in medical treatment and psychosocial survivorship research. Cancer 2012;118:4824-32.

82. Kim SE, Paik HY, Yoon H, et al. Sex- and gender-specific disparities in colorectal cancer risk. World $\mathcal{7}$ Gastroenterol 2015;21:5167-75.

83. Kunath F, Keck B, Bertz S, et al. Is gender becoming relevant in urooncological research? A bibliographical analysis. World 7 Urol 2013;31: $1065-72$

84. Arnetz L, Ekberg NR, Alvarsson M. Sex differences in type 2 diabetes: focus on disease course and outcomes. Diabetes Metab Syndr Obes 2014;7:409-20.

85. Franconi F, Campesi I, Occhioni S, et al. Sex-gender differences in diabetes vascular complications and treatment. Endocr Metab Immune Disord Drug Targets 2012;12:179-96.

86. Franconi F, Campesi I. Sex and gender influences on pharmacological response: an overview. Expert Rev Clin Pharmacol 2014;7:469-85.

87. Keuken DG, Haafkens JA, Moerman CJ, et al. Attention to sex-related factors in the development of clinical practice guidelines. 7 Womens Health (Larchmt) 2007;16:82-92.
88. Clayton JA, Collins FS. Policy: NIH to balance sex in cell and animal studies. Nature 2014:509:282-3.

89. Johnson J, Sharman Z, Vissandjee B, et al. Does a change in health research funding policy related to the integration of sex and gender have an impact? PLoS One 2014;9:e99900.

90. Morris ZS, Wooding S, Grant J. The answer is 17 years, what is the question understanding time lags in translational research. 7 R Soc Med 2011;104:510-20.

91. Hanney SR, Castle-Clarke S, Grant J, et al. How long does biomedical research take? Studying the time taken between biomedical and health research and its translation into products, policy, and practice. Health Res Policy Syst 2015;13:1.

92. Sorge RE, Mapplebeck JC, Rosen S, et al. Different immune cells mediate mechanical pain hypersensitivity in male and female mice. Nat Neurosci 2015; 18:1081-3.

93. Valiyeva E, Herrmann N, Rochon PA, et al. Effect of regulatory warnings on antipsychotic prescription rates among elderly patients with dementia: a population-based time-series analysis. CMA7 2008;179:438-46.

94. Keuken DG, Haafkens JA, Mohrs J, et al. Evaluating the effectiveness of an educational and feedback intervention aimed at improving consideration of sex differences in guideline development. Qual Saf Health Care 2010;19:e18.

95. Keuken D, Bindels P, Klazinga N, et al. A systematic approach for uptake of evidence on sex-specific issues in guidelines - a pilot study. 7 Eval Clin Pract 2012;18:369-77.

96. Handbook on clinical practice guidelines. Ottawa: Canadian Medical Association; 2007. Available: https://www.cma.ca/Assets/assets-library/document/en/ clinical-resources/CPG\%20handbook-e.pdf (accessed 2015 Apr. 26).

97. Brouwers MC, Kho ME, Browman GP, et al.; AGREE Next Steps Consortium. AGREE II: advancing guideline development, reporting and evaluation in health care. CMA7 2010;182:E839-42.

98. Alonso-Coello P, Schunemann HJ, Moberg J, et al.; GRADE Working Group. GRADE Evidence to Decision (EtD) frameworks: a systematic and transparent approach to making well informed healthcare choices. 1: Introduction. BMF 2016;353:i2016.

99. Guyatt GH, Oxman AD, Vist G, et al. GRADE guidelines: 4. Rating the quality of evidence - study limitations (risk of bias). 7 Clin Epidemiol 2011; 64:407-15.

100. Schünemann HJ, Mustafa R, Brozek J, et al.; GRADE Working Group. GRADE guidelines: 16. GRADE evidence to decision frameworks for tests in clinical practice and public health. 7 Clin Epidemiol 2016;76:89-98.

101. Welch VA, Petticrew M, O'Neill J, et al. Health equity: evidence synthesis and knowledge translation methods. Syst Rev 2013;2:43.

102. De Castro P, Heidari S, Babor TF. Sex and Gender Equity in Research (SAGER): reporting guidelines as a framewark of innovation for an equitable approach to gender medicine. Commentary. Ann Ist Super Sanita 2016;52: 154-7.

103. Song MM, Simonsen CK, Wilson JD, et al. Development of a PubMedbased search tool for identifying sex and gender specific health literature. $f$ Womens Health (Larchmt) 2016;25:181-7.

Affiliations: Faculties of Medicine and Pharmacy (Tannenbaum), Université de Montréal; Centre de Recherche (Tannenbaum), Institut universitaire de Gériatrie de Montréal, Université de Montréal; Institute of Gender and Health (Tannenbaum, Voss), Canadian Institutes of Health Research, Montréal, Que.; Barbara Clow Consulting (Clow); Department of History (Clow), Faculty of Graduate Studies, Dalhousie University, Halifax, NS; Department of Sociology (Haworth-Brockman), Faculty of Arts, University of Winnipeg; Rady Faculty of Health Sciences (Haworth-Brockman), National Collaborating Centre for Infectious Diseases, University of Manitoba, Winnipeg, Man.

Contributors: Barbara Clow and Margaret Haworth-Brockman performed the search for clinical practice guidelines and searched the guidelines for sex and gender keywords. Cara Tannenbaum, Barbara Clow and Margaret Haworth-Brockman analyzed and categorized the guidelines. All of the authors drafted the manuscript, revised it critically, approved the final version to be published and agreed to act as guarantors of the work.

Supplemental information: For reviewer comments and the original submission of this manuscript, please see www.cmajopen.ca/content/5/1/ E66/supp1/DC1 